\title{
Portrait of Cyber Sexual Violence Understanding on Indonesia Millennials
}

\author{
Tri Hastuti Nur Rochimah ${ }^{1 *}$, and Wuri Rahmawati ${ }^{2}$
}

\begin{abstract}
${ }^{1}$ Department of Communication, Faculty of Social and Political Sciences, Universitas Muhammadiyah Yogyakarta, Indonesia ${ }^{2}$ Department of Communication, Faculty of Economics, Social Sciences, and Humanities, Universitas Aisyiyah Yogyakarta, Indonesia

${ }^{*}$ Corresponding author: trinur@umy.ac.id
\end{abstract}

\begin{abstract}
The number of cyber sexual violence is increasing. Based on Women National Commissioner annual report, cases of violence against women have increased. There is a new pattern of violence against women called cyber sexual violence. This research aims to describe various cyber sexual violence faced by women, particularly teenagers. The research method used to answer the objective in this study is quantitative descriptive. Data were collected using a questionnaire (Google forms) to millennials, in-depth interviews, an FGD, and documentation. This study revealed that millennials living in a digital space had at least four social media platforms. However, they possessed inadequate digital literacy of privacy protection and cyber sexual violence understanding like cyber grooming. Understanding and awareness of both victims and perpetrators, legal system and policies not supportive of prevention, and patriarchal culture in society were factors of cyber sexual violence. Therefore, policy on violence in the digital platform must be established by the government. The government and other stakeholders should perform literacy for millennials regarding varieties of sexual violence on social media.
\end{abstract}

Keywords: cyber sexual violence, digital, millennial, SDGs

\section{INTRODUCTION}

Cyber sexual violence cases are increasing. Based on the National Women Commissioner annual report, within 12 years of violence against women, cases increased by 792 percent. This increase continued in the last three years (2017-2020). There emerged a new pattern of violence against women called cyber sexual violence. In 2020, the number of cyber sexual violence continued to increase (Komnas Perempuan, 2020). This increase is directly in line with the development of social media platforms. Social media has become a renowned platform allowing people to express their feelings with the added advantage of being in disguise and perpetrate acts of violence against their peers, such as bullying, harassment, dating aggression, and gangrelated crimes (Cash et al. 2013 in Vivek, 2017). In the Indonesian context, research of Digital 2021: the Latest Insights Into The State of Digital explained that from the total population of 274.9 million, 170 million use social media, dominated by millennials. The most used social media applications are YouTube, WhatsApp, Instagram, Facebook and Twitter (Kompas, 2021).

The increase in violence against women, including cyber sexual violence, has become a global concern, as stated in the Sustainability Development Goals (SDGs), particularly in the fifth goal-achieving gender equality and empowering all women and girls. Such an increase aligns with the social media development in Indonesia and the millennials' low understanding of cyber sexual violence. The high number of sexual violence in society, including the millennials, is directly proportional to the increase in cyberspace violence. The technological development creating social media or virtual networks has weakened women by positioning them as objects of violence. Adolescent girls who are social media users are ultimately vulnerable to the risk of online crime (Jatmiko et al., 2020). (Jane, 2017) argued that more and more women are targeted by online harassment, and that experiences with gendered cyberhate are no longer limited to women in the public sphere. The limited understanding of gender inequality, especially in millennials, affects gender violence awareness through social media.

Many factors cause the increase in gender-based violence, such as the understanding and awareness of both victims and perpetrators, the legal system and policies not supportive of prevention, recovery assistance, and the strong construction of patriarchal culture in society, which instead blames victims of violence and unequal relations between men and women.

Research conducted by (Mercedes, Osuna et al., 2020) discovered a strong and significant correlation between knowledge on violence, sources of information, and unequal relationship conditions with the level of gender-based violence. The more they understand and are aware of gender-based violence, such as sexual harassment, rape, incest, domestic violence, violence during courtship, the less 
likely they will experience violent acts in the future. In the Indonesian context, the increasing number of violence in cyberspace for millennials has not received serious attention due to a lack of understanding about online gender-based violence. Violence is considered normal and even made a laughing stock (ridicule). This research is significant in answering various cyber sexual violence women face, particularly millennials, along with the development of technology on various digital platforms becoming part of millennials' daily lives. This research aims to explore the level of understanding of millennials on cyber sexual violence and discover the forms of cyber sexual violence they face.

\section{THEORETICAL FRAMEWORK}

Social media is "a group of internet-based applications that build on the ideological and technical foundations of Web 2.0 and allow the creation and exchange of usergenerated content" (Kaplan, 2015). Social media characters are inexpensive and completely free to use. The use of social media can be categorized into seven benefits, as suggested by (Whiting \& Williams, 2013): (1) as a communication tool, (2) for a place to find information, (3) as social interaction, (4) as entertainment or relaxation through watching videos or music, (5) free time filler, (6) as an empty time-filler, and (7) online business.

Millennials have dominated the growth of social media in the world and Indonesia. The world of millennials is digital. Even one teenager has at least four social media accounts, and all of his life is spent interacting with social media. Instagram (IG) and Twitter are the most widely used social media by students (Rahmawati, 2018). The impact of social media development has changed the communication patterns of millennials. Participative internet use, which most individuals recognize as "social media," has revolutionized and transformed communication patterns, especially in teens (Plaisime et al., 2020). Social media has become an integral part of today's millennials. It is not just a medium to stave off boredom or works as a time-filler. It has started to significantly impact their education, knowledge, and exposure to new experiences (Vivek, 2017).

The growth of social media has provided opportunities for violence against other groups, both women (genderbased violence) and minority, or as a medium to attack each other. Referred to (Huesmann, 2007), social media violence can be defined as "any badgering or tormenting (prodding, telling untruths, ridiculing somebody, making inconsiderate or mean remarks, spreading bits of gossip, or making debilitating or forceful remarks) that happens through email, a talk room, texting, a site (counting online journals), or content informing. There are many factors of violence through social media, and one of them is related to social media characteristics. Anonymity makes it possible to forge new online identities, assuming a different age, gender, beliefs, or other personal attributes (Darias, 2017).
Cyber sexual violence is an act of physical and nonphysical violence perpetrated by one gender or an institution in the family, community, or state against the other gender. It can occur due to an inaccurate understanding of the differences in the character or nature of women and men (Fakih, 2013). The view that women are weak, obedient, and quiet can encourage arbitrary treatment such as sexual harassment, domestic violence, rape, prostitution, sexual exploitation, genital mutilation, and others (Afandi, 2019). Gender-based violence targets a person because of her/his gender (Andersson N, Cockcroft A, 2008). CEDAW defined gender-based violence as violence that disproportionately affects women's lives. All theories refer to violence based on sex. Cyber sexual violence is rampant, ranging from sexual harassment of public figures on social media to stalking intimate partners using special applications (Nicolas, Suzor; Molly, Dragiewic; Bridget, 2018). Forms of cyber sexual violence cover a spectrum of behavior, including stalking, intimidation, sexual harassment, defamation, hate speech and exploitation (Kusuma, Ellen \& Veda, 2020).

Cyber sexual violence frequently occurs due to the lack of protection of a person's data, where some parties or individuals misuse it to carry out various forms of violence. The violence includes threats and intimidation to spread pornographic photos or videos of victims, use of abusive language, insults, threats of sexual violence, body shaming, cyber grooming, cyber harassment, hacking, illegal content, infringement of privacy, malicious distribution, online defamation and online recruitment (Kusuma, Ellen \& Veda, 2020). The violence in cyberspace can impact the attitudes and behavior of victims in their daily lives, such as low selfesteem, stress, feeling insecure, having to change places of residence or school, having to leave the media platforms used, and making changes in expressing themselves. However, not all millennials understand that they have experienced cyber sexual violence online or have seen individuals using it to commit various forms of violence. Despite having understood the matter, not all victims have the willingness to report it. This condition is closely related to the level of comprehensive knowledge of millennials on online cyber sexual violence.

In various studies increasingly concerned with the impact of communication technology in our society, a thorough understanding of the relationship between information and communication technology and violencebased gender is still far from expected (Ravan Elena in Segrave and Laura, 2017).

\section{RESEARCH METHOD}

This research employed a quantitative descriptive method to achieve the objectives. (Kriyantono, 2020) explained that quantitative descriptive research is a process to understand phenomena based on methodological steps to analyzing data by describing systematically, factually and accurately about the facts and characteristics of a particular 
population or object. The results of the analysis are more in the form of the percentage of processes and results of a phenomenon. This research method uses deductive thinking, namely the data obtained from the application of theories. This study utilized four data collection techniques: a questionnaire through Google forms, in-depth interviews, an FGD, and documentation.

The questionnaire was distributed to 290 male and female respondents aged 17-22 years using the incidental sampling technique. The results of the questionnaire coding were then used as a basis for obtaining more information on cyber sexual violence through in-depth interviews and an FGD. The informants consisted of eight teenage girls and boys. The FGD involved ten millennials using social media, both male and female. The use of various data collection techniques and informants is part of conducting research triangulation.

\section{FINDINGS AND DISCUSSION}

\subsection{Social Media Habit of Millennials}

Millennials refer to groups with the potential and assets of the nation in the future but have not received attention from various parties, including state policies. Referring to the Beijing Platform for Action (BPfA) in 1995, millennials are crucial groups in the development process. In 1995, the BPfA set out the most comprehensive blueprint for women's rights and gender equality to date. Twenty-five years on, there is still a long way to achieve gender equality (BPfA, 1995). This research is in line with Plan International's research in 2020, which involved more than 14,000 girls aged 14-22 years in 22 countries, including Indonesia. There have been $58 \%$ of women experiencing sexual harassment online and $50 \%$ also admitted that they experienced more sexual harassment online than offline.

Respondents' profiles based on social media ownership depict that, on average, teens have at least four social media accounts. Social media is part of the lives of millennials in Indonesia. Meikle stressed that social media describes a specific set of internet-based networked communication platforms using a database business model built by its users. Moreover, they enable the convergence of public and personal communication (Meikle, 2016). Based on the media ownership of millennials, they frequently access 17 social media, and on average, each has four social media accounts, which can be seen in the following table:
Table 1. Social Media Accounts and Uses among Indonesian Millennials

\begin{tabular}{|l|l|r|r|r|r|}
\hline \multirow{2}{*}{ No } & \multirow{2}{*}{$\begin{array}{l}\text { Social } \\
\end{array}$} & Media & \multicolumn{2}{|c|}{ Social Media Account } & \multicolumn{2}{|c|}{ Social Media Uses } \\
\cline { 3 - 6 } & Number & \multicolumn{1}{c|}{$\%$} & Number & \multicolumn{1}{c|}{$\%$} \\
\hline 1 & WhatsApp & 290 & $100 \%$ & 290 & $100 \%$ \\
\hline 2 & Instagram & 290 & $100 \%$ & 205 & $70.69 \%$ \\
\hline 3 & Twitter & 135 & $46.55 \%$ & 122 & $42.06 \%$ \\
\hline 4 & Line & 125 & $43.10 \%$ & 50 & $17.61 \%$ \\
\hline 5 & Facebook & 102 & $35.17 \%$ & 68 & $23.44 \%$ \\
\hline 6 & Telegram & 60 & $20.69 \%$ & 37 & $12.76 \%$ \\
\hline 7 & Tik Tok & 55 & $18.96 \%$ & 46 & $15.86 \%$ \\
\hline 8 & Youtube & 42 & $14.48 \%$ & 32 & $11.03 \%$ \\
\hline 9 & Discord & 17 & $5.86 \%$ & 5 & $1.72 \%$ \\
\hline 10 & Snapchat & 7 & $2.41 \%$ & - & - \\
\hline 11 & Pinterest & 6 & $2.06 \%$ & - & - \\
\hline 12 & KakaoTalk & 3 & $1.03 \%$ & - & - \\
\hline 13 & Steam & 3 & 1.03 & - & - \\
\hline 14 & Weverse & 2 & $0.06 \%$ & - & - \\
\hline 15 & Skype & 1 & $0.03 \%$ & - & - \\
\hline 16 & Path & 1 & $0.03 \%$ & - & - \\
\hline 17 & Weibo & 1 & $0.03 \%$ & - & - \\
\hline
\end{tabular}

Source: Questionnaire Data, 2021

Table 1 displays that all millennials have WhatsApp and Instagram accounts. The top five social media were WhatsApp, Instagram, Twitter, Line, and Facebook. This study unveiled that although having social media accounts, they did not operate all of them, such as Snapchat, Pinterest, KakaoTalk, Steam, Weverse, Skype, Path and Weibo. They were interested in social media accounts with the characteristics of being able to send photos, images, videos, and messages in writing. This research discovered that Indonesian millennials had at least four media accounts: WhatsApp, Instagram, Twitter, FB and Tik Tok.

WhatsApp was used as the main social media to build millennials' daily communication with family, friends, teachers or lecturers. In contrast, Instagram and Twitter were mostly used to convey personal information by sending pictures, photos, and videos with short messages. Instagram has provided easy and attractive features for millennials, making them feel comfortable to access it at any time. Indonesian millennials were generally members of WhatsApp Group (WAG) families, schools/colleges, communities, friends, alumni, sports teams, tutoring, organizations, committees, business/work, online games, and COVID-19 volunteers. Through WAG, Instagram and Twitter, information can be spread quickly to all members. This finding is in line with the explanation from (Meikle, 2016) about the characteristics of social media, making it close to millennials. Social media are platforms combining what we used to think of as public with what we used to think of as personal communication. Both now take place in the same frame. Public messages - news stories, music videos, advertisements, stand-up comedy routines, political speeches, film trailers-are copied and circulated, repositioned and recontextualized every day by hundreds of millions of users of Facebook and Twitter, Google and 
YouTube, Instagram and Pinterest. Public media become personalized, as each message is embedded within a new context as part of an individual user's online identity performance. Furthermore, those same users make their comments and opinions, emotions, prejudices and beliefs, and secrets and virtues visible to others. Personal communication takes on a public aspect.

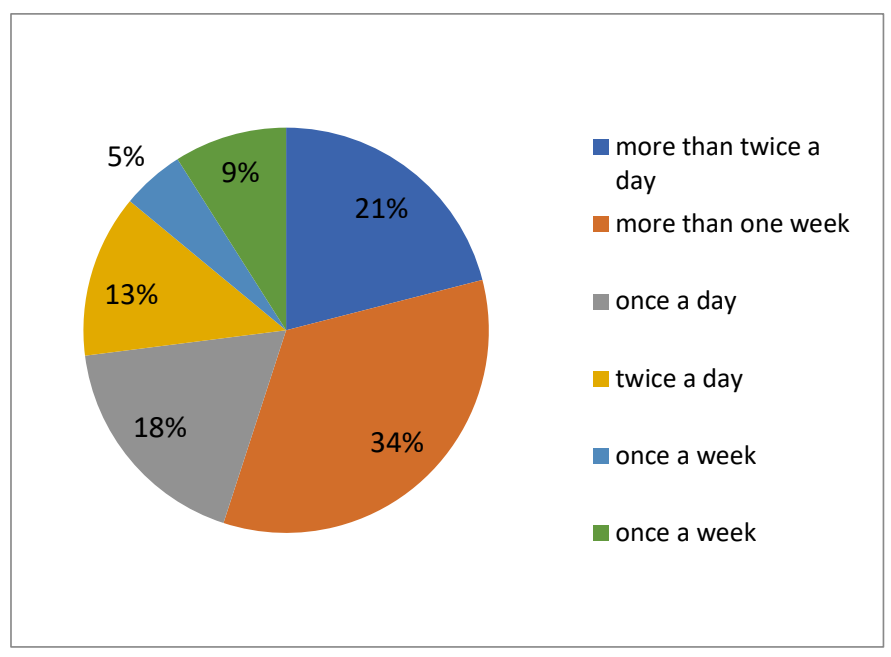

Chart 1. Millennials' Users Status Updates on Social Media Accounts

Source: Questionnaire Data, 2021

Chart 1 demonstrates that most millennials (34\%) update their social media status more than once a week, $5 \%$ once a week, and 9\% once in three days. Millennials opened social media to obtain much information from friends or the public about certain issues or topics. Some intensively updated information on their social media, $21 \%$ more than twice a day, $18 \%$ once a day, and $13 \%$ twice a day.

On social media, millennials share information about themselves, family, friends, girlfriends, tourism destinations, culinary and so on. Every teenager has the freedom to upload information. Moreover, this study disclosed that most millennials shared information about themselves on their social media.

This research showed that $83.34 \%$ of millennials frequently upload photos of themselves or their groups and express their feelings and property. Furthermore, the topics uploaded were about tourism destinations (69.65\%), friends $(68.95 \%)$, family $(47.24 \%)$, culinary $(45.86 \%)$, and partner $(13.10 \%)$. Only a few millennials uploaded about their partners because most were afraid or worried if their parents found out they were dating.

Regarding their habit of using social media, (Tao Hu, Thomas F. Stafford, William J. Kettinger, 2018) mentioned that social media usage habit is how people use social media automatically to meet personal needs in the voluntary environment. Social media behavior means actions taken by millennials when accessing various social media, including accepting invitations to make friends, receiving or replying to inbox messages or private networks or direct messages, commenting or responding to other people's comments and so on.

This study uncovered that most millennials (65\%) searched the profiles of people asking for friendship before deciding to accept them. In addition, 31\% searched and looked for friends being members of social media and invited them as friends, and $4 \%$ immediately approved friend requests on their social media accounts. They accepted new friend requests because they were friends outside of social media (58\%), had many mutual friends $(30 \%)$, and those asking to be friends were famous people or public figures (12\%).

It is a precautionary measure to minimize fraud, crime, and harassment to prevent millennials from getting harm or risk either physically, mentally, or materially. Making friends in cyberspace must be more careful and selective.

\subsection{Media Exposure and Knowledge of Cyber-Sexual Violence $(K G B O)$}

To explain how millennials are exposed to media, we refer to Donald Roberts about media exposure. His study calculated media exposure simply as the total time youngsters spent with each medium (Roberts, 2000). This research discovered that $72.8 \%$ had heard of cyber sexual violence while the remaining $27.2 \%$ never had. Sources of information regarding cyber sexual violence include social media, television news, campuses, news portals, friends, parents, webinars, posters, newspapers, magazines, brothers, neighbors, tabloids and radio, as depicted in the following table.

Social media is the main source of information about cyber sexual violence for millennials (77.24\%). It is relevant to the fact that millennials are highly closed to social media. They can access various information without boundaries of space, time and energy. Mobile is no longer a luxury. The source of cyber sexual violence information is obtained either directly or using oral or through media (channel). Sources of verbal information include parents, siblings, friends, neighbors, education on campus, webinars or seminars and radio. Furthermore of cyber sexual violence knowledge level is displayed in the following table:

\section{Table 2. Knowledge Level of Cyber Sexual Violence}

\begin{tabular}{|l|l|r|r|}
\hline No & $\begin{array}{c}\text { Definition and Concept } \\
\text { of Cyber Sexual } \\
\text { Violence }\end{array}$ & Number & \% \\
\hline 1 & Cyber grooming & 105 & $36.20 \%$ \\
\hline 2 & Cyber trafficking & 130 & $44.80 \%$ \\
\hline 3 & Malicious distribution & 139 & $47.90 \%$ \\
\hline 4 & Morphing & 153 & $52.80 \%$ \\
\hline 5 & Online prostitution & 178 & $61.40 \%$ \\
\hline 6 & $\begin{array}{l}\text { Sharing porn pictures } \\
\text { and videos to other }\end{array}$ & 189 & $65.20 \%$ \\
\hline
\end{tabular}




\begin{tabular}{|l|l|r|r|}
\hline 7 & Cyber harassment & 191 & $65.90 \%$ \\
\hline 8 & Illegal content & 193 & $66.60 \%$ \\
\hline 9 & $\begin{array}{l}\text { Non-consensual } \\
\text { disseminate intimate } \\
\text { images }\end{array}$ & 198 & $68.30 \%$ \\
\hline 10 & Cyber pornography & 202 & $69.70 \%$ \\
\hline 11 & Cyber stalking & 205 & $70.70 \%$ \\
\hline 12 & $\begin{array}{l}\text { Moersonation/cloning/id } \\
\text { entity falsification }\end{array}$ & 206 & $71.00 \%$ \\
\hline 13 & Online defamation & 226 & $77.90 \%$ \\
\hline 14 & Hacking & 234 & $80.70 \%$ \\
\hline
\end{tabular}

Source: Questionnaire Data, 2021

This violence attacks a person's body, sexuality, and gender identity facilitated by digital technology. Most of the victims of online sexual violence are millennials. From the gender aspect, those vulnerable to being victims are women. Table 2 exhibits that millennials have a knowledge level about cyber sexual violence of $62.79 \%$, with the most knowledge about hacking at $80.70 \%$ and the lowest about cyber grooming at $36.20 \%$. Hacking is a term most widely known by millennials because there are often hacks of various social media accounts, both Instagram, Facebook, Twitter, and so on. The data reveal that cyber grooming, cyber trafficking, and malicious distribution frequently occurred. Unfortunately, many millennials did not understand that some were acts of online gender-based violence. They did not realize that cyber grooming was the beginning of an online sexual assault and that cyber grooming must be watched out for. Concerning cyber grooming, according to Williams et al. (2013), it is difficult to identify sexual grooming, especially if it occurs on the internet. The researchers stated three stages to online grooming: (a) rapport building, (b) sexual content, and (c) assessment. It is argued that groomers plan the process in careful detail to build a relationship to gain trust. Following the trust-building stage, the person moves to the sexual content stage (Whiting \& Williams, 2013).

Similarly, of cyber sexual violence forms, a few millennials (under 50\%) understood that malicious distribution was cyber sexual violence. (McGlynn \& Rackley, 2017) explained that advances in technology have transformed and expanded how sexual violence can be perpetrated. Furthermore, (McGlynn \& Rackley, 2017) stressed that revenge porn has joined a host of other equal media-friendly monikers used to describe a specific type of non-consensual image-based harm. Following the table above, it is crucial to provide literacy to increase the knowledge and understanding of adolescents about terms, concepts, forms and ways to deal with various issues regarding cyber sexual violence. One of reasoning for the low understanding and insight of women in the digital realm is the factor of gender construction in the community. Women are positioned as parties easily deceived and pressured by irresponsible people.

\subsection{Responses and Experiences of Millennials of Cyber Sexual Violence (KBGO)}

Technology is both a weapon and a shield when it comes to violence against women and girls in public spaces and private places (Marganski \& Melander, 2021). The development of the digital world with its various characteristics turns out to be prone to encourage onlinebased sexual violence. The dichotic nature of digital progress concerning violence against women and girls suggests that much more needs to be done to address and prevent increasingly common episodes of technologyfacilitated gender violence, especially for vulnerable and marginalized groups, to exact positive cultural change.

Meanwhile, the groups vulnerable to experiencing cyber sexual violence, according to the results of this study, are dating partners $(78.4 \%)$, rape victims $(67.2 \%)$, actors $(62.8)$, friendship relationships (55.9), victims of domestic violence (50 .3\%), politicians (30.7\%), married couples (24.5\%), journalists (20.3\%), and writers (16.2\%). These data indicate that cyber sexual violence among millennials during courtship frequently occurs, and generally, it is female millennials who become victims. Ay, an informant in the FGD, stated that:

"...A friend once sent a photo to his girlfriend without clothes on, because the guy asked, "do you love me or not?" Blind love, passionate love. When they were fighting to break up, the guy threatened to spread it (the nude photo) to other people. So, she was afraid to leave the guy..." (Ay, 26 June 2021)

The dating phenomenon among teenagers has been a trend that exceeds the boundaries of religious and social norms. Thus, it triggers them to do things that should not be done because, legally, the state and religiously, these teenage couples are not yet legal. At any time, the courtship can end without a trial process. Moreover, women are more disadvantaged as they worry or fear that if the relationship ends, nude photos can be disseminated through social media, become a topic of discussion in male groups if they are no longer virgins, and so on. This study indicates that the factors causing a person or group of people to do cyber sexual violence on millennials include sexual desire $(84.8 \%)$, anger $(81.1 \%)$, jealousy $(74.4 \%)$, the need for money $(74,2 \%)$, revenge $(72.7 \%)$, political agenda $(60.7 \%)$, maintaining social status $(46.2 \%)$, want to show love $(36.5 \%)$, and affection $(34.2 \%)$.

Millennials experiencing cyber sexual violence encounter psychological burdens, social isolation, economic loss, and reduced mobility and self-censorship. They become insecure about interacting or socializing with their environment, even to the point of withdrawing or moving away by staying in their room, changing schools, or dropping out of school. Some then intend to end their lives by committing suicide. In the FGD, Tk mentioned as follows: 
“... I am experiencing body shaming. When passing by, I was called, hey plump; you have a big ass, a big body, where do you hang out? I felt sad but still grateful for having complete limbs. But, there was a friend of mine who rode a motorcycle in the rain because her unclothed photos were uploaded to Facebook by his ex-boyfriend..." (Tk, 26 June 2021).

Such conditions hinder millennials from being able to develop themselves, work and or achieve. The results of this study unveiled that $79.7 \%$ of adolescents realized that they could experience cyber sexual violence at any time, either directly or through their social media. Moreover, when experiencing cyber sexual violence, they would tell family or friends $(92.4 \%)$, block the perpetrator's account $(89 \%)$, document things that happened $(77.6 \%)$, and feel embarrassed, and hide it $(23.1 \%)$. It is as stated by $\mathrm{Rr}$ in the FGD that she immediately blocked the account of a friend who did cyber sexual violence:

"...I make friends with people having the same interest on the internet, namely Korean stuff. The account is fun. We made ordinary conversation. In the middle of the conversation, he asked me, if you go to Jogja, do you want to play and sleep with me? Hey, what do you mean? Yes, we can fall asleep groping. After that, I immediately blocked his account as I was afraid that he might change accounts..." (Rr, 26 June 2021)

On the other hand, $99.7 \%$ of millennials were willing to accompany their friends experiencing cyber sexual violence to resolve their case. It implies that millennials can be continuously involved in cyber sexual violence literacy efforts, prevention and assistance to other victims of cyber sexual violence. Therefore, various efforts to increase the knowledge and understanding of millennials about terms, concepts, forms and ways to deal with various issues regarding cyber sexual violence must be increased to avoid misunderstandings. Efforts to minimize the incidence of cyber sexual violence in millennials are crucial. One of which is the preparation of national policies contained in technical regulations to minimize millennials experiencing cyber sexual violence. Cyber sexual violence victims are still experiencing difficulties and confusion. How to complain about what they have experienced? There must be a complaint service and special assistance for millennials victims of cyber sexual violence. Hence, they have the opportunity to achieve meaningful dreams and hopes for the future.

One essential factor is the characteristics of social media, where people can attack and make derogatory comments on women because accounts can be anonymous (Zhong et al., 2020). The environment afforded by the internet allows people to express themselves in a relatively uninhibited manner compared to real-world interactions (Suler, 2004). This phenomenon is referred to as 'online disinhibition' (Joinson, 1998). If inhibition consists of behavioral constraint because of individuals' anxieties and self- consciousness from an audience, disinhibition is the absence of these feelings due to the lack of an obvious audience.

The Plan International Survey reveals that these women expect various changes to combat this problem, from education about cyber sexual violence to government intervention through legal policies and the importance of reporting mechanisms through social media platforms. Unfortunately, Indonesia has not owned clear regulations regarding online gender-based violence.

\section{CONCLUSIONS}

Millennials have dominated social media usage in Indonesia. Every teenager had at least four social media accounts, and they spent 4-7 hours a day interacting with others on social media. Of the cyber sexual violence, social media have been the main source of information for millennials to obtain information about cyber sexual violence. Moreover, most of the cyber sexual violence victims are millennials. From the gender aspect, those vulnerable to being victims are women. This study revealed that millennials had average knowledge of cyber sexual violence of $62.79 \%$, with the most knowledge about hacking and the lowest knowledge of cyber grooming. Many factors have caused the high and increasing numbers of cyber sexual violence, such as the understanding and awareness of both victims and perpetrators, the legal system and policies not supportive of prevention, recovery assistance, the strong construction of patriarchal culture in society, which instead blames victims of violence and unequal relations between men and women.

\section{AUTHORS' CONTRIBUTIONS}

The first author conceived and designed an instrument for collecting data, designed the analysis, contributed data, performed the analysis and wrote the paper. The second author collected data and wrote the paper.

\section{ACKNOWLEDGMENTS}

The authors would like to thank stakeholders who supported the implementation and publication of this research, namely Universitas Muhammadiyah Yogyakarta, Universitas 'Aisyiyah Yogyakarta, Millennials who participated as respondents and informants for our research, and students involved in collecting data.

\section{REFERENCES}

[1] Afandi, A. (2019). Bentuk-Bentuk Perilaku Bias Gender. Lentera:Journal of Gender and Children Studies, 1(1), 1-18.

[2] Andersson N, Cockcroft A, and S. B. (2008). Gender-based violence and HIV: relevance for HIV prevention in hyperendemic countries of southern Africa. AIDS, 4, S73S86. https://doi.org/10.1097/01.aids.0000341778.73038.86 
[3] Cresswell, John W and Miller, D. L. (2020). Determining Validity in Qualitative Inquiry: Theory Into Practice. College of Education, The Ohio State University.

[4] Darias, A. (2017). Gender-Based Harassment in Cyberspace. The Case of Pikara Magazine, Women's Studies International Forum. https://www.researchgate.net/publication/320576750

[5] Fakih, M. (2013). Analisis Gender dan Transformasi Sosial. Pustaka Pelajar.

[6] https://dictionary.cambridge.org/dictionary/english/grooming (2021). Grooming: Meaning in The Cambridge English Dictionary. Cambridge Dictionary. https://dictionary.cambridge.org/dictionary/english/grooming

[7] https://plan-international.org/publications/setting-agendagirls-platform-action. (2020). Setting The Agenda: Girls Platform for Action. Plan International. https://planinternational.org/publications/setting-agenda-girls-platformaction

[8] https://tekno.kompas.com/read/2021/02/24/08050027/risetungkap-lebih-dari-separuh-penduduk-indonesia-melek-mediasosial. (2021). Riset Ungkap Lebih dari Separuh Penduduk Indonesia "Melek" Media Sosial. Https://Tekno.Kompas.Com/Read/2021/02/24/08050027/Rise t-Ungkap-Lebih-Dari-Separuh-Penduduk-Indonesia-MelekMedia-Sosial.

https://tekno.kompas.com/read/2021/02/24/08050027/risetungkap-lebih-dari-separuh-penduduk-indonesia-melek-mediasosial.

[9] https://www.sdg2030indonesia.org/page/13-tujuan-lima. (2017). Ringkasan Meta Data Indikator Tujuan Pembangunan Berkelanjutan (Sustainability Development Goals), Kementrian Perencanaan Pembangunan. https://www.sdg2030indonesia.org/page/13-tujuan-lima

[10] Https://www.un.org/en/events/pastevents/pdfs/Beijing_Declar ation_and_Platform_for_Action.pdf. (1995). Beijing Declaration and Platform for Action. https://www.un.org/en/events/pastevents/pdfs/Beijing_Declara tion_and_Platform_for_Action.pdf

[11] Huesmann, R. (2007). The Impact of Electronic Media Violence: Scientific Theory and Research. Journal of MillennialsHealth, https://doi.org/10.1016/j.jadohealth.2007.09.005

[12] Jane, E. A. (2017). Feminist flight and fight responses to gendered cyberhate. In Gender, technology and violence (1st ed.).

[13] Jatmiko, M. I., Syukron, M., \& Mekarsari, Y. (2020). Covid19, Harassment and Social Media: A Study of Gender-Based Violence Facilitated by Technology During the Pandemic. The Journal of Society and Media, 4(2), 319. https://doi.org/10.26740/jsm.v4n2.p319-347

[14] Kaplan, A. M. (2015). Social Media, the Digital Revolution, and the Business of Media. JMM International Journal on Media Management, 17(4), 197-199. https://doi.org/10.1080/14241277.2015.1120014

[15] KomnasPerempuan. (2020). Siaran Pers dan Lembar Fakta Komnas Perempuan: Catatan Tahunan Kekerasan terhadap Perempuan 2020. https://komnasperempuan.go.id/siaran-persdetail/catahu-2020-komnas-perempuan-lembar-fakta-danpoin-kunci-5-maret-202

[16] Kusuma, Ellen \& Veda, J. A. (2020). Panduan Sigap Hadapi Penyebaran Konten Intin Non Konsensual: Aku Harus Bagaimana? SAFEnet. https://s.id/panduankbgo
[17] Marganski, A. J., \& Melander, L. A. (2021). TechnologyFacilitated Violence Against Women and Girls in Public and Private Spheres: Moving from Enemy to Ally. The Emerald International Handbook of Technology Facilitated Violence and Abuse, 623-641. https://doi.org/10.1108/978-1-83982848-520211046

[18] McGlynn, C., \& Rackley, E. (2017). Image-based sexual abuse. Oxford Journal of Legal Studies, 37(3), 534-561. https://doi.org/10.1093/ojls/gqw033

[19] Meikle, G. (2016). Social Media: Communication, Sharing and Visibility (I). Routledge 711 Third Avenue, New York, NY 10017 and by Routledge 2 Park Square, Milton Park, Abingdon, Oxon OX14 4RN.

[20] Mercedes, Osuna;Luis, Manuel and Irene, D. (2020). Perception of Gender-Based Violence and Sexual Harassment in University Students: Analysis of the Information Sources and Risk within a Relationship. International Journal Environment Research and Public Health, 17(11).

[21] Nicolas, Suzor; Molly, Dragiewic; Bridget, H. (2018). Human Rights by Design: The Responsibilities of Social Media Platforms to Address Gender-Based Violence Online. Policy and Internet Journal, 11(1), 84-103.

[22] Plaisime, M., Robertson-James, C., Mejia, L., Núñez, A., Wolf, J., \& Reels, S. (2020). Social Media and Teens: A Needs Assessment Exploring the Potential Role of Social Media in Promoting Health. Social Media and Society, 6(1). https://doi.org/10.1177/2056305119886025

[23] Rahmawati, W. (2018). PENERIMAAN MASYARAKAT TERHADAP PESAN KESEHATAN MELALUI MEDIA INTERNET. 7(1).

[24] Ravan Elena in Segrave and Laura. (2017). Gender, Technology and Violence.

[25] Roberts, D. F. (2000). Media and millennials: access, exposure, and privatization. Journal of Adolescent Health, 27, S8-S14. https://doi.org/10.1016/s1054-139x(00)00128-2

[26] Salim, A. (2006). Teori dan Paradigma Penelitian Sosial. Tiara Wacana.

[27] Tao Hu, Thomas F. Stafford, William J. Kettinger, X. "Paul" Z. \& H. D. (2018). Formation and Effect of Social Media Usage Habit. Journal of Computer Information Systems, 58(4), 334-343 https://doi.org/10.1080/08874417.2016.1261378

[28] Vivek, T. (2017). Millennials Violence and Social Media. Journal of Social Sciences, 52. https://doi.org/10.1080/09718923.2017.1352614

[29] Whiting, A., \& Williams, D. (2013). Why people use social media: a uses and gratifications approach. Qualitative Market Research: An International Journal, 16(4), 362-369. https://doi.org/10.1108/QMR-06-2013-0041

[30] Zhong, L. R., Kebbell, M. R., \& Webster, J. L. (2020). An exploratory study of technology-facilitated Sexual Violence in online romantic interactions: Can the Internet's toxic disinhibition exacerbate sexual aggression? Computers in Human Behavior, 108 https://doi.org/10.1016/j.chb.2020.106314 